Magnus Hontvedt

Universitetet i Sørøst-Norge

Morten Oddvik

Universitetet i Sørøst-Norge

Rakel Rohde Ncess

Universitetet i Sørøst-Norge

DOI: http://dx.doi.org/10.5617/adno.7916

\title{
Videolekser som ressurs for lesing og undervisning i lærerutdanning - En studie av hvordan samarbeid og partnerskap kan utvikles rundt lærerstudenters videoinnspilte leserefleksjoner
}

\begin{abstract}
Sammendrag
Denne artikkelen rapporterer fra et pågående designeksperiment der et konsept kalt «videolekser» ble introdusert for å få innsikt i lærerstudenters lese- og læringsprosess. Konseptet ble laget i samarbeid mellom underviserne på universitetet og en lærer i kombinasjonsstilling.

Videoleksene innebar at studentene spilte inn korte filmer der de reflekterte over egen lesing før de møtte til undervisning. Prosjektet ble gjennomført i et masteremne (år 4 av 5) ved et norsk universitet. Studien følger til sammen 47 lærerstudenter som tok emnet i løpet av en to-årsperiode. Datamaterialet består av 118 refleksjonsvideoer. Materialet er kodet, og utvalgte utdrag fra filmene presenteres og analyseres med interaksjonsanalyse.

I artikkelen synliggjøres videoleksene som en form for videobasert støtte til lærerstudentenes lese- og læreprosess, med mulighet for å komme i kontakt med studentenes ofte «tause» selvstendige lesing. Studien konkluderer med at bruken av video har potensial til å skape felles fokus, og under bestemte forutsetninger bidra til å skape partnerskap og relevans i lærerutdanningen.
\end{abstract}

Nøkkelord: partnerskap, kombinasjonsstillinger, IKT og læring, interaksjonsanalyse, videolekser 


\title{
Video assignments as resources for reading and instruction in teacher education - A study on how collaboration and partnership can be developed around teacher students' video- recorded reading reflections
}

\begin{abstract}
This study reports from an ongoing design experiment in which a concept called "video assignments” was introduced for accessing teacher students' reading and learning process. The concept was designed in collaboration between lecturers at the university and a practicing teacher in a combined position.

The video assignments entailed that students recorded short video clips in which they reflected on their reading prior to meeting in class. The project was conducted at a master's level course (year 4 of 5) at a Norwegian university. There were 47 students who participated in the course over a two-year period, and the data material consists of 118 video reflections. The material was coded, and selected extracts from the videos are presented and analyzed by means of interaction analysis.

In the article, the video assignments are displayed as a form of video-based support to the students' studying and learning process, with opportunity for accessing the students' often "silent" individual reading process. This study concludes that the use of video has potential for creating a common focal point, and under certain prerequisites contributing to creating partnership and relevance in teacher education.
\end{abstract}

Keywords: partnerships, combined positions, ICT and learning, interaction analysis, video assignments

\section{Introduksjon}

Denne artikkelen rapporterer fra et pågående utviklingsarbeid der et konsept kalt videolekser ble skapt for å få innsikt i lærerstudenters lese- og læringsprosess på et samlingsbasert masterstudium i profesjonsrettet pedagogikk. Videoleksene innebar at studentene spilte inn korte filmer på opptil 5 minutter som de lastet opp til emnets læringsplattform før hver samling. Her reflekterte de over emnelitteraturen de hadde lest, hva de syntes var interessant/vanskelig og hva de ønsket seg på neste undervisningsøkt. Underviserteamets målsetting var å skape en ny grenseflate mot studentenes selvstendige lese- og læringsprosess, som igjen kunne danne et omdreiningspunkt for planleggingen av læringsaktiviteter. Teamet var nyetablert med en lærer i kombinasjonsstilling. Denne stillingstypen er del av en større satsing for å utvikle partnerskap og relevans i lærerutdanningen på Universitetet i Sørøst-Norge (USN), og innebærer at lærere fra skolen får bistilling ved universitetet i opp mot $20 \%$ stilling. Denne artikkelen viser hvordan utviklingen av videolekseprosjektet både var et resultat av, og en ressurs for, samarbeidet i underviserteamet. Deler av teamet er også forfattere av denne artikkelen. 
I den nasjonale strategien for kvalitet og samarbeid i lærerutdanningene, Lærerutdanning 2025, etterlyses sterkere samarbeidsrelasjoner mellom lærerutdanningene og praksisfeltet slik at studieprogrammene utvikles i tråd med profesjonens oppgaver og utfordringer (Kunnskapsdepartementet, 2017). For å realisere en slik integrert utdanning med helhet og sammenheng, skal partnerskapet mellom skoler og universitet styrkes gjennom felles forsknings- og utviklingsprosjekter og samarbeid om undervisning og studieaktiviteter (Meld. St. 16 (2016-17)). Mot denne utdanningspolitiske bakgrunnen blir det tydelig at stillingskategorien lærer i kombinasjonsstilling adresserer sentrale utfordringer i sektoren: Dette er stillinger opprettet ved universitetet for fagpersoner fra praksisfeltet. Formålet med stillingstypen er at lærere og ledere i praksisfeltet kan bidra til å gjøre undervisningen ved universitetet mer profesjonsrettet, praksisnær og relevant.

Profesjonell utvikling på teamnivå er viktig, men utfordrende å få til i høyere utdanning (Gast, Schildkamp \& Van der Veen, 2017). Dette gjelder også samarbeid på tvers av faglige domener. Tidligere forskning på interprofesjonelt samarbeid har vist at det er utfordrende å realisere felles forståelse og reelle arbeidsfellesskap, og at det er fruktbart å skape felles objekter for samarbeid (Edwards, Lunt \& Stamou, 2010).

I artikkelen følger vi utviklingen av et slikt felles objekt - videoleksene gjennom to semestre, og drøfter hvordan dette bidro til å konkretisere og orientere undervisernes teamarbeid mot studenters lese- og læreprosess. Prosjektet retter seg i så måte mot en aktuell utfordring i høyere utdanning: Studenter er forventet å bruke mye tid på selvstendig lesing av fagstoff, men det kan være utfordrende for undervisere å komme i kontakt med disse ofte individuelle og «tause» prosessene (Baker, Bangeni, Burke \& Hunma, 2019).

Den pågående studien er definert som et designeksperiment (Brown, 1992; Krange \& Ludvigsen, 2009). Designeksperimenter i utdanningsfeltet kjennetegnes som teoridrevne innovasjonsprosjekter der undervisningspraksis og forskning samspiller. Til grunn for utvikling og analyse ligger et sosiokulturelt perspektiv på læring (Vygotsky, 1978; Daniels, 2008).

\section{Forskningsspørsmål}

- Hvordan tok studentene videoleksene i bruk for å reflektere over egen leseprosess, diskutere emnelitteratur og prøve ut profesjonsspesifikke begreper?

- Hvordan ble videolekser etablert som et felles objekt for samarbeid mellom undervisere i høyere utdanning?

I det følgende gjør vi først rede for sentrale utfordringer knyttet til samarbeid og partnerskap i lærerutdanning, før vi diskuterer betydningen av samhandling og samarbeid i profesjonsutdanning. Her etableres bruk av video som en mulig 
strategi for å møte noen av utfordringene på feltet. Kapitlet om forskningsdesign beskriver hvordan studien ble utformet og gjennomført. Den påfølgende analysedelen har tre deler: Først drøftes designet av videoleksene, før vi presenterer interaksjonsanalyser (Jordan \& Henderson, 1995) av første års videolekser. Siste delen av analysen viser overordnede trekk ved studentenes besvarelser fremvist gjennom koding av materialet i sin helhet etter gjennomføringen av begge semestre (Derry et al., 2010). I diskusjonsdelen besvarer vi de to forskningsspørsmålene og sammenfatter overordnede funn og implikasjoner.

\section{Samarbeid og partnerskap i lærerutdanningen}

Norsk lærerutdanning har gjennomgått omfattende reformer de siste årene. I Nasjonal strategi for kvalitet og samarbeid i lærerutdanningene, «Lærerutdanning 2025» (Kunnskapsdepartementet, 2017), er ett av fire overordnede mål å stimulere samarbeid mellom skoler og lærerutdanninger og mellom barnehager og barnehagelærerutdanninger. Samarbeidet skal være stabilt og gjensidig utviklende, og skal bedre studenters opplevelse av manglende samsvar mellom opplæring på campus og det som skjer i skolen. Dette dilemmaet er godt dokumentert i NOKUTs (2006) evaluering av lærerutdanningene. Evalueringen fremhevet at praksis var et kritisk element i utdanningen. Opplevelsen av manglende samsvar ble også bekreftet i SINTEFs kartlegging av studiekvalitet i de ulike lærerutdanningene (Finne, Jensberg, Aaslid, Haugsbakken, Mathisen \& Mordal, 2011).

Internasjonal forskning peker på at en av de sentrale utfordringene $\mathrm{i}$ lærerutdanning er å skape fruktbare koblinger mellom universitetsutdanningen og profesjonen det utdannes til (Ellis, 2016). Dette handler om å balansere fokuset på praktisk kunnskap om undervisning, med teoretisk og forskningsbasert kunnskap om læring (Buehl \& Fives, 2009). Studier har også vist hvordan lærerstudenter finner det utfordrende å rekontekstualisere det som er lært i lærerutdanningen i praksissituasjoner (Nolen, Horn, Ward \& Childers, 2011).

Lærerutdanning forutsetter samarbeid mellom ulike fagmiljøer og fagpersoner som innehar ulike former for kompetanse, og det kan være problematisk for studentene å håndtere slike ulike kunnskapskulturer (Hermansen \& Mausethagen, 2016). Forskning har vist hvordan studentene kan bli stående alene om å utvikle sammenhenger mellom teorien fra lærerutdanning og praksisen i klasserommet. I slike situasjoner ville de ha tjent på en felles diskurs om lærerstudentenes læring der ekspertisen fra begge steder verdsettes (Jahreie, 2010).

Det som ofte betegnes som teori-praksis-utfordringer, involverer overganger mellom en rekke ulike kontekster for læring og anvendelse av kunnskap (Sannino, Daniels \& Gutiérrez, 2009). Lærerutdanningenes kontekster involverer blant annet undervisning på campus, praksisperioder i skolen og senere yrkesliv. Eller som denne artikkelen setter fokus på: utfordringene knyttet til overføring av 
erfaringer fra selvstendig lesing av fag- og forskningslitteratur inn mot undervisnings- og praksisaktiviteter. Selvstendig lesing av akademiske tekster er etablert som en sentral læringsaktivitet i høyere utdanning. Faglitteraturen er ment for å innvie studentene i et profesjonelt fellesskap, og danne grunnlag for forskningsbasert praksis. Men tekstene er ofte utfordrende å forstå, og sikrer ikke alene et felles profesjonsgrunnlag. Hovdenak og Wiese (2017) påpeker at det er en trussel mot kvaliteten i lærerutdanning at studenter ikke leser pensum, og at dette begrenser muligheten til å organisere fruktbare og kunnskapsbaserte diskusjonsaktiviteter på campus.

Forskning har vist hvordan undervisernes bruk av faglitteraturen har stor betydning for utvikling av studenters forståelse, og at innrammingen lesingen gis i utdanningen påvirker det som kan betegnes som dybde- og overflatestrategier (Marton \& Säljö, 1976). Dybdestrategier beskriver lesemønstre der studentene orienterer seg mot tekstenes mening og hovedbudskap, mens overflatestrategier beskriver et fokus på memorering og gjentakelser av innhold. Ut fra en slik dikotomi vil det være fruktbart for studenter å få hjelp til å utvikle forståelse for begreper og sammenhenger, fremfor mer fragmenterte biter av informasjon. Selv om selvstendig lesing av faglitteratur er en sentral læringsaktivitet, er det likevel en aktivitet som i liten grad er observerbar for undervisere og som forstås på ulike måter av studenter og undervisere. Dette byr på særlige utfordringer fordi den akademiske diskursen har vist seg vanskelig å dekode for nykommere (Heller \& Morek, 2015). Ofte vurderes studenters kunnskapsforståelse som et spørsmål om modning, og at de utvikler mer dybdeorienterte læringsstrategier utover i studieløpet. Asikainen og Gijbels’ (2017) forskningsgjennomgang viser at det ikke er tilfelle at dette skjer av seg selv. De påpeker at forskningen er sprikende og ufullstendig, og ikke støtter spesifikke programmer eller strategier for dybdelæring. De etterlyser flere studier av dette, blant annet på emne- og oppgavenivå der kontekstuelle faktorer i større grad tas inn i analysen.

Samlet aktualiserer dette behov for forsknings- og utviklingsprosjekter som i større grad ser på hvordan lærerstudenter konstruerer og transformerer kunnskap i lærerutdanningens ulike kontekster. Dette innebærer også studier av de kontekstene læringen konstrueres i (Fosse, 2016), samt hvordan høyere utdanning kan møte disse utfordringene gjennom økt samarbeid på teamnivå (Gast, Schildkamp \& Van der Veen, 2017).

\section{Læring gjennom aktiv deltakelse og samhandling}

Denne studien inntar et sosiokulturelt perspektiv på utvikling av profesjonalitet gjennom deltakelse i sosial praksis (Vygotsky, 1978; Daniels, 2008). Dette perspektivet bidrar til å forstå både undervisernes samarbeid og lærerstudentenes læreprosess og innvielse i et profesjonsfaglig fellesskap. Tidligere studier har 
demonstrert hvordan det å være en profesjonsutøver innebærer å ha et profesjonsfaglig blikk og et sett profesjonsspesifikke begreper for å beskrive og oppfatte verden (Goodwin, 1994, 1995). Dette viser en dobbelt betydning av tilegnelse av forskningsbasert kunnskapsgrunnlag i lærergjerningen: Teori bidrar til å knytte konkrete observasjoner og opplevelser til større forklaringssystem, samt med ressurser for å se kompleksitet og (re)organisere erfaring (Suppes, 1974). I et sosiokulturelt perspektiv kan ikke innholdselementer isoleres fra språket og symbolene disse medieres gjennom. Begreper danner slik en optikk for å se og kategorisere verden på profesjonsspesifikke måter. I et sosiokulturelt perspektiv er det sentralt hvordan det å lære handler om transformasjon av hvordan verden konseptualiseres (Edwards \& D'Arcy, 2004, s. 147).

it may be [...] useful to consider conceptual knowledge as, in some ways, similar to a set of tools. Tools share several significant features with knowledge: They can only be fully understood through use, and using them entails both changing the user's view of the world and adopting the belief system of the culture in which they are used

(Brown, Collins \& Duguid, 1989, s. 33)

Profesjonalitet ses i en slik sammenheng som konstruert og utøvet i sosial praksis, i motsetning til å ses som et stabilt sett med ferdigheter eller egenskaper (Edwards, 2010). Profesjonsutdanning profiterer på å aktivt søke og skape situasjoner hvor studenter møter grenseoverganger mellom ulike praksiser - som mellom utdanning- og arbeidssituasjoner (Bronkhorst \& Akkerman, 2016). Mot denne bakgrunnen danner ikke videoleksene en infrastruktur for å «sikre læring», men artefakter som gis mening i sosiokulturell praksis (Petraglia, 1998; Silseth, 2012). Snarere er videoleksene en arena for studentene til å interagere med underviserne og litteraturen i emnet, og skape et objekt for samarbeid mellom underviserne i emnet. Slike læringsaktiviteter har vist seg utfordrende å skape i høyere utdanning, fordi det forutsetter dialog mellom studenter og undervisere som er krevende å skape i forelesningssituasjoner. Videoformatet har i så måte visse bruksmuligheter som ikke fullt ut er utforsket i høyere utdanning.

\section{Video som ressurs for samhandling og deltakelse $i$ høyere utdanning}

Digitale teknologier - som datamaskiner, mobiltelefoner og sosiale medier - har skapt nye muligheter for læringsaktiviteter i skole og utdanning, så vel som endret behovet for kompetanse i samfunnet det utdannes til (Collins \& Halverson, 2010). Når vi søker i forskningslitteraturen, finner vi en rekke måter video anvendes på i undervisningsaktiviteter i høyere utdanning:

Microteaching har vært et tema for forskning gjennom flere tiår og innebærer at lærerstudenter arbeider systematisk med konkrete undervisningssituasjoner gjerne videoobservasjoner fra klasserom - på campus (Allen, 1980). de Lange og Nerland viser hvordan microteaching kan være en verdifull aktivitet for å koble ulike emner og kunnskapsdomener i lærerutdanning, men også at det er utfordrende å løfte studentenes kommentarer om situerte handlinger til mer stabile 
utfordringer i yrket og teoretisk forankrede problemstillinger (de Lange \& Nerland, 2018). Videobasert microteaching innebærer at videoopptak fra undervisningssituasjoner anvendes for å fasilitere refleksjon, og at drøfting av teori kobles til konkrete undervisningssituasjoner (Kourieos, 2016).

Søk etter video feedback i høyere utdanning viser flere studier der video anvendes som ressurs for å gi tilbakemelding til studentene. Mahoney, Macfarlane og Ajjawi (2019) viste i sin forskningsgjennomgang at mens tekst- og audiofeedback har blitt forsket mye på, så har det vært mindre fokus på videofeedback. Deres studie viser at til tross for at metodene viser potensial for å konkretisere tilbakemeldinger til studenter, bærer forskningen preg av småskalaundersøkelser og selvrapportering. Studien viser videre at selv om videomediet i seg selv har rike muligheter for dialog, er det primært brukt til overføring av informasjon (Mahoney, Macfarlane \& Ajjawi, 2019).

Videoblogger og videopodkaster er også former for videobasert teknologi som anvendes i høyere utdanning. Kay (2012) gjorde en forskningsgjennomgang på videopodkaster i høyere utdanning og fant at bruken i hovedsak var knyttet til forelesere som laget podkaster som studentene kunne se og lytte til - men de fant få eksempler på studentproduserte videopodkaster. Det har skjedd mye med podcaster og videoblogging siden 2012, men i våre søk vi funnet få forskningsstudier som belyser slik bruk i høyere utdanning. Det har vært mye fokus på lærerproduserte videoer i det som ofte betegnes som omvendt undervisning. Men her er det også fokus på at lærere sender sine innspill og vurderinger til studentene, ikke fra studenter til lærer (Lundin, Bergviken Rensfeldt, Hillman, LantzAndersson \& Peterson, 2018). Blant unntakene er noen studier på bruk av studentproduserte videoer i språkundervisningen, der studenter demonstrerer språklige ferdigheter som sendes til læreren (Meyer \& Forester, 2015).

Mot denne bakgrunnen plasserer vår studie seg blant en rekke studier som analyserer bruk av video for studentaktive læringsformer i høyere utdanning, men er så vidt vi kan vurdere alene om å studere studenters videorefleksjoner som en systematisk måte å komme i kontakt med deres selvstendige lese- og læreprosess, og som ressurs for utforming av læringsaktiviteter på campus.

\section{Forskningsdesign}

\section{Setting og informanter}

Studien ble gjennomført på et masteremne (år 4 av 5) ved USN, og forfatterne var selv involvert i undervisningen. Denne artikkelen beskriver utprøvingen og utviklingen av videolekseprosjektet gjennom to gjennomføringer av det samme emnet. Emnet var fordelt på 6 samlinger per semester. Undervisningen var en kombinasjon av forelesninger, ekskursjoner og studentdrevet aktivitet. Det første året var det 25 lærerstudenter med ulike fagkretser som tok emnet og som leverte tre videolekser fordelt utover høstsemesteret. Det påfølgende året var det 22 
lærerstudenter som tok emnet. Denne andre gruppen leverte også tre videolekser, hvorav to hadde samme oppgave og utforming som året før.

\section{Data}

Som undervisere har vi detaljert kunnskap om alle samlingene, med forelesninger, arbeidskrav, gjennomført muntlig eksamen og studentenes emneevaluering. Emneevalueringen siste år fokuserte særlig på bruken av videolekser og ble hentet inn etter avsluttet eksamen gjennom Nettskjema (https://nettskjema.no). 19 av 22 studenter besvarte denne.

Det primære datamaterialet for studien består av 118 videolekser - altså filmsnutter med varighet på opptil 5 minutter som studentene selv spilte inn i løpet av semesteret. Av disse var 57 fra det første året og 41 fra det andre året leserefleksjoner. De 98 filmene som inneholder leserefleksjoner er kodet tematisk, og utvalgte utdrag fra filmene presenteres og analyseres i detalj ved hjelp av interaksjonsanalyse (Derry et al., 2010; Jordan \& Henderson, 1995). 20 av videoleksene fra det andre året inneholdt refleksjoner over praksisperioden. Siden disse videoene hadde et annet formål, er de ikke kodet sammen med de resterende. Antallet videolekser er lavere enn antall studenter ganget med antall innleveringer; det er på grunn av noen fritak på grunn av sykdom samt at to studenter ikke ønsket å ta del i forskningsdelen av prosjektet.

\section{Analyseprosess}

Analysen består av tre deler som beskriver innovasjon og overordnet forløp, analyser av utdrag fra videoleksene og til slutt en analyse av overordnede trekk og fremtidig utvikling.

For beskrivelse av den institusjonelle konteksten for utviklingen av partnerskap har vi anvendt interne utredninger og strategidokumenter. Videoleksene har vi analysert etter prinsipper fra interaksjonsanalyse (Jordan \& Henderson, 1995). Selv om filmene er monologer, så studeres de i interaksjonsanalysene som ytringer i en dialogisk relasjon til emnelitteraturen, policy, forelesninger og undervisere. Policy omfatter i denne sammenheng utdanningspolitiske styringsdokumenter, veiledninger og utredninger.

Analyseutdragene fra videoleksene representerer ulike stabile orienteringer mot utfordringer knyttet til overganger mellom forelesninger og selvstendig lesing, relasjoner mellom ulike deler av emnelitteraturen - samt overganger mellom undervisningen på universitetet og undervisningspraksis i skolen. Dette var elementer som studentene orienterte seg mot, og som var særlig relevante for våre forskningsspørsmål. Utdragene er valgt fordi de representerer generelle utfordringer som er relevante for mange studenter, men også fordi de illustrerer hva slags type situasjoner som vi ønsker å stimulere til. Denne type designeksperimenter har som mål å legge til rette for det som kan betegnes som «bestcase scenario» (Roth, 2006, s. 36). Utdragene representerer i så måte aspekter som 
vi oppfattet som interessante å vurdere i videre forskning og utvikling, samtidig som de vurderes og drøftes kritisk.

Studentvideoene ble transkribert i sin helhet og analysert i forskergruppen etter begge gjennomføringer. Tematiske koder ble konstruert med utgangspunkt i interaksjonsanalysene og prosjektets målsettinger (Derry et al., 2010, s. 20). Alle transkriptene ble kodet med analyseverktøyet NVivo 12. Målet med kodingen var å kartlegge materialet i sin helhet, kategorisere fenomener vi var særlig interesserte i, og vurdere eventuell utvikling og endring mellom gjennomføringene. Denne kartleggingen presenteres og drøftes nærmere i analysekapitlet sammen med evaluering og videreutvikling.

\section{Forskningsetiske betraktninger}

Prosjektet ble meldt til NSD, og det ble utformet et formelt samtykkebrev som ble formidlet til studentene. Filmene ble levert gjennom en læringsplattform med Feide-innlogging, og ble slettet etter at de var lastet over på et eksternt lagringsmedium.

Det var frivillig for studentene om de ville delta og dele videofilmene til forskningsøyemed. Det ble uttrykt muntlig og skriftlig at det ikke ville få noen negative konsekvenser for studentene om de valgte å ikke delta. Studenter som ikke ville være med, ble følgelig ikke inkludert i materialet. Vi har tatt grep for å bevare anonymitet, som endringer i kjønn og yrkeserfaring i presentasjonen av studenter. Videoleksene er også prøvd ut i flere klasser, som gjør det lettere å holde anonymiteten selv om undervisere og institusjon er kjent. Vi har heller ikke oppgitt nøyaktig hvilke semestre datainnsamlingen ble gjort.

\section{Begrensninger}

I likhet med andre studier har denne studien hatt en rekke utfordringer og begrensninger som vi har forsøkt å imøtekomme. I designeksperimenter kan det være en trussel mot kvaliteten at forskerne har investert mye tid $\mathrm{i}$ at eksperimentet skal fungere godt, og av den grunn vektlegger positive aspekter og såkalt «cherrypicking». For å unngå dette ble det vektlagt at de ulike forskerne og underviserne inntok ulike roller i prosjektet. Det er også vektlagt beskrivelser av målsettingene og konteksten videoleksene inngår i. Det er sentralt at primærdataene er selve studentvideoene - som det i større grad er anledning til å behandle systematisk og vurdere for andre forskere som ikke har vært aktive i gjennomføringen.

\section{Analyse}

I dette kapitlet analyseres bakgrunnen for utviklingen av videoleksene, selve videoleksene og også hvordan resultatene ble benyttet for å videreutvikle prosjektet. De tre hoveddelene av kapitlet er kalt «Analyse I: Innovasjon og 
overordnet forløp», «Analyse II: Studentenes videolekser» og til slutt «Analyse III: Evaluering og videreutvikling av videolekseprosjektet».

\section{Analyse I:}

\section{Innovasjon og overordnet forløp}

På institusjonsnivå kan samarbeidet som her beskrives, spores tilbake til strategidokumentet «Lærerutdanning 2025» og at grunnskolelærerutdanningene høsten 2017 ble femårige masterutdanninger. Enheten USN Profesjon ble utviklet for å koble, styrke og videreutvikle samarbeidet mellom universitetet og praksisfeltet (USN, 2019a). Denne var en pådriver for å legge til rette for kombinasjonsstillinger med formålet at lærere og ledere i praksisfeltet kan bidra til å gjøre undervisningen ved universitetet mer profesjonsrettet, praksisnær og relevant for studentene. Ordningen skal bidra til at problemstillinger, utfordringer og arbeidsmåter fra praksisfeltet inngår som del av undervisningen på campus, eller som kunnskapsutviklingsprosjekter i praksis (USN, 2019b). Et viktig premiss for kombinasjonsstillingene er at de besettes av personer som blir kallet til kombinasjonsstilling; dette muliggjør at man i stor grad vektlegger kompetanse som ønskes på teamnivå. I dette tilfellet ønsket vi noen med erfaring med IKT og læring. De som ansettes, inngår i underviserteam i 10-20 \% årsverk for en periode på to år, og kan også bidra til felles forsknings- og utviklingsarbeid (USN, 2019b).

Med bakgrunn i dette ble det ansatt en lærer fra videregående skole, også med rolle som «digitalpedagog», for å styrke profesjonsrelevansen og arbeidet med IKT. Læreren satt på relevante erfaringer blant annet fra nettundervisning, som bidro med inspirasjon til å tenke nytt om undervisningen på universitetet. Teamet delte et ønske om å trekke samarbeidet inn i selve undervisningen og benytte denne stillingstypen til å tilrettelegge for diskusjoner om «teori» og «praksis» med studentene. Slik dialog forutsetter imidlertid noe konkret å samarbeide om og en felles forståelse blant underviserne om hvor studentene er i sin læringsprosess og hvordan slike diskusjoner kan gjøres forskningsrelevante.

Det ble derfor bestemt at et felles fokus skulle være å støtte studentenes læreprosess mellom samlingene. Erfaring fra tidligere gjennomføring av lignende emner tilsa at studenter opplevde at det er krevende å få lest og reflektert over emnelitteraturen, samtidig som de opplevde det vanskelig å knytte faglitteraturen til praksiserfaringene sine. Dette initierte utviklingen av en digital plattform for videoinnleveringer - videolekser. Videoene spilte en sentral rolle i planleggingen av samlingene, og de dannet utgangspunkt for en mer detaljert forståelse for hva studentene hadde tilegnet seg av kunnskap. Utover innsiktene i leseprosessen, ga videoene også en mulighet til raskt å lære seg studentenes navn, ansikt og interesseområder. Dette ble opplevd som en effektiv måte å få kjennskap og relasjon til hver enkelt student - en relasjon som ofte kan ta lang tid å etablere i helklassesituasjoner og på samlingsbaserte studier. Videolekseprosjektet ble på dette tidspunktet også definert som et forsknings- og utviklingsprosjekt med mål om en vitenskapelig publikasjon der lærer i kombinasjonsstilling tok del. 
Videoleksene representerer en måte å samle og behandle studentenes videomedierte leserefleksjoner på i forkant av undervisningen. Det er dette designet som er grunnlaget for å beskrive utviklingsarbeidet som en innovasjon. Teknologisk er det flere ulike ressurser som støtter en slik praksis. I dette tilfellet kunne verktøyet integreres i universitetets læringsplattform Canvas. Dette innebar at studentene kunne bruke sine studentkontoer for pålogging og bruk av plattformen.

For videoleksene ble innstillingene satt til at bare underviserne kunne se filmene. Dette valget ble tatt fordi studentene ønsket det, og for at de skulle være komfortable til å ta opp ting de var usikre på uten at det var synlig for medstudenter. Vi vurderer imidlertid at det er et potensial for student-student-respons, og vil forsøke ut dette senere med litt ulike oppgavetyper og formater i tillegg til leserefleksjonene som her beskrives.

\section{Analyse II:}

\section{Studentenes videolekser}

Etter gjennomføringen av det første året, ble videoleksene analysert i detalj. I filmene sitter studentene oftest alene og snakker til kamera. De hadde gjerne med seg bøker og tekster som de viste frem mens de snakket. Noen ganger satt de også på offentlige steder som i kantina eller på kafe. Studentene holdt seg alle til oppgaven og fortalte om sin leseaktivitet siden sist. Oppgaven var: Fortell om tekstene du har lest siden sist. Hva synes du var interessant, nyttig eller vanskelig i tekstene? Hva ønsker du deg fra forelesningen som kommer?

Selv om oppgaven var lik for alle, kunne fokuset deres ha relativt ulik orientering. I de følgende delkapitlene analyserer vi tre slike trekk i detalj: «Videoleksene som gjensidig ansvarliggjørende objekt for samarbeid», «Sammenheng og motsetninger i emnelitteraturen» og «Profesjonsspesifikke begreper som linse for å betrakte og utvikle egen undervisning». I utdragene er tekstene transkribert ordrett, med sekunder i parentes for å vise pauser. Parentes med kun punktum signaliserer kort pause på under to tidels sekund. Understreking viser økt trykk på ord, og store bokstaver signaliserer økt volum. Hehe betyr latter. Kolon benyttes for å vise at vokaler «strekkes», slik man gjerne gjør når man leter etter ord eller tenker seg om.

\section{Videoleksene som gjensidig ansvarliggjørende objekt for samarbeid}

Et av målene for prosjektet var å ansvarliggjøre studentene for lesing, og også ansvarliggjøre underviserne for å møte studentenes interesser og behov på samlingene. Overgangen fra selvstendig lesing til å produsere en video synliggjøres ofte som en krevende oppgave for studentene, men gir også anledning til å involvere de emneansvarlige i læreprosessen. Denne tosidige forpliktelsen er blant annet observerbar i Stein sin videolekse. I det følgende utdraget ser vi hvordan videoleksene skaper en forventning om å ha lest og at noe burde vært gjort mellom samlingene. 
Utdrag 1: Stein, om ansvarliggjøring av studentene:

1 Hei:: e:h ja. nå er jeg veldig veldig veldig for se:n hehe til

2 fristen (.) e:h jeg synes det har vært ganske vanskelig à lage

3 denne videoen. Det skulle egentlig bare være noe veldig kjapt og

4 enkelt, men jeg bare (0.8) tror jeg har gjort (0.2) den har blitt

5 for la:ng, og jeg har ikke vært fornø:yd, og (.) ja (.) jeg synes

6 det har vært veldig vanskelig, og det har tatt mye tid (0.2) jeg

7 har brukt (1.0) jeg har laget så mange forskjellige videoer heh

8 som jeg ikke har vært fornøyd med (.) så nå har jeg bare bestemt

9 (.) nå må jeg bare få levert (.) så jeg beklager veldig at jeg

10 er så forsinka, det skal ikke skje igjen. Neste gang skal jeg

11 heh selvfølgelig levere til fristen (.) jeg tenkte å bare lage

12 denne her veldig, veldig kort, sånn at jeg har levert noe, hvert

13 fall eh (0.1) jeg har jo lest mye siden sist

Som vi ser fremhever Stein at dette har vært en utfordrende oppgave. Han presiserer at det var meningen å gjøre dette kjapt og enkelt, men har tilsynelatende opplevd at det var vanskelig å uttrykke noe overordnet om lesingen, og har gjort flere innspillinger som han ikke har vært fornøyd med (L 7-8). Han beklager at han er så sen, og presiserer at neste gang skal han levere til fristen. Det er interessant å se siste linje (L 13), hvor han også presiserer at han har lest mye siden sist. Det er mer uklart hva som er grunnen til at det da har vært utfordrende - om han har vært veldig kritisk til egen forståelse eller om det har vært utfordrende å rekontekstualisere det som er lest til en mer samtalende formidlingsform.

En slik rekontekstualisering og artikulering kan i så fall være en nyttig øvelse for studenten, og videoleksene setter en tid og anledning for at dette gjøres - selv om man fortsatt er usikker. Utdraget viser hvordan videoleksene skaper en arena for å dele egen leseprosess med underviserne, men også at det kan være krevende å omstille seg og artikulere en sammenfatning av det man har lest.

I det neste utdraget ser vi en annen dimensjon ved dette samme poenget, som handler om studentenes ansvarliggjøring av underviserne. Her er det en annen av studentene som etterlyser mer forklaring på et vanskelig tema som ble drøftet på forrige samling. Hun har fortalt om sin lesing av boken «Læring - en introduksjon av perspektiver og metaforer» (Säljö, Gilje \& Goveia, 2016) og går over i en refleksjon over hva slike teorier og metaforer kan anvendes til: 
Utdrag 2: Iben, om ansvarliggjøring av undervisere:

1 teksten var nyttig den har jo gitt meg noe ny innsikt på hva

2 læring er, som jeg forhåpentligvis kan bruke når jeg skal (.)

3 planlegge undervisning $i$ framtida (.) både $i$ praksis og som

4 framtidig lærer $(0.5)$ e:h je:g (.) fortsatt lurer jeg litt på

5 om det hadde vært mulig om dere kunne hjelpe med å

6 eksemplifisere hva de forskjellige læri:ngsteoriene er $i$ en

7 lærerhverdag (.) vi hørte jo $i$ forrige forelesning om at for

8 eksempel at det er ikke sosiokulturelt (.) eller at det må ikke

9 være sosiokulturelt bare fordi du jobber $i$ grupper (.) men det

10 hadde også vært litt fint å kanskje få noen eksempler på hva

11 som er sosiokulturelt og hva som behavioristisk og hva som e:r

12 kognitivt og ikke bare (0.2) kunne hjulpet meg å få satt det

13 litt bedre på plass hvis vi kunne fått opp noen eksempler på

14 hva som er de forskjellige læringsteoriene også (.) i en lærers

15 hverdag (.) ikke bare via teoriene vi leser $i$ boka

I dette utdraget ser vi altså en student som forteller om sin lesing av boka «Læring - en introduksjon av perspektiver og metaforer». Selv om hun anerkjenner at lesingen var nyttig (L 1-3), så er det fortsatt noe som skurrer for henne i relasjon til en diskusjonssak fra forrige forelesning, der foreleseren kritiserte at sosiokulturell læringsteori noen ganger blir nedjustert til «gruppearbeid» (L 8-9). Iben kunne spurt om dette på forelesningen, men gjorde det ikke. Også i linje 4 ser vi en pause og markering av at spørsmålsstillingen vurderes. I spørsmålet bruker hun også formuleringen «hjelpe med» (L 5) som plasserer ansvaret for å forstå dette på henne selv. Studentens tilbakemelding er viktig, for det er tydelig at selv om det på forelesning ble hevdet at en slik bruk av et sosiokulturelt læringsperspektiv er overforenklet - så ble det ikke tydelig for studenten(e) hva teorien faktisk kan benyttes til. Måten spørsmålet stilles på viser også at det noen ganger kan være utfordrende å fremheve det man ikke helt har forstått og ansvarliggjøre underviserne. I linje 10-15 ser vi hvordan hun etterlyser nettopp en bedre forklaring på relasjonen mellom teori og praksissituasjoner på den kommende samlingen.

Tematisk er dette lett å kjenne igjen fra gjennomgangen av policy så vel som tidligere forskning, at det er utfordrende å se relevansen i forskningsteoriene for skolepraksis. Men utdraget viser også at videoleksene gir en tilleggsarena for å stille spørsmål og komme med innspill til campusaktiviteter. På denne måten demonstreres et potensial i videoleksene; det gjør studenters ofte «tause» leseprosess mer transparent for underviserne. Dette gir grunnlag for planlegging av forelesninger og samlinger på en måte som kan være vanskelig å organisere i tradisjonelle universitetssettinger.

\section{Sammenheng og motsetninger i emnelitteraturen}

I det følgende utdraget illustreres en annen tilnærming til lesingen, nærmere bestemt hvordan håndtere relasjonen mellom ulike tekster på litteraturlisten og hvordan det samme begrepet refereres til mellom ulike deler av forskningslitteraturen. Louise har bøker og artikler liggende foran seg og løfter og viser 
tekstene etter hvert som hun forteller. Vi kommer inn tidlig i videoen, hvor hun akkurat har presisert at hun velger å fokusere på begrepet kreativitet.

\section{Utdrag 3: Louise, om kreativitet som begrep i emnelitteratur og policy:}

Eh Vygotsky knytter kreativitet, eller en kreativ handling (0.9) til enhver menneskelig handling som resulterer $i$ noe nytt (1.4) Han skiller mellom reproduktive aktiviteter og kombinerende eller kreative aktiviteter (.) Reproduktive, der reproduserer du noe, mens kombinerende, eller kreative aktiviteter, der kombinerer du (.) momenter for eksempel fra tidligere innhentede erfaringer eller forkunnskaper (.) bruker det og omsetter de til et nytt produkt enten mentalt eller fysiske (.) ja (.) så denne kombinerende aktiviteten knytter han til imagination" fantasi forestillingsevne (0.4) og beskriver at kreativitet er til stede når en person imagines (0.5) eh og det jeg synes er interessant da, med denne definisjonen, er at kreativitet dermed blir noe man har skapt og utviklet, og noe alle elever vil inneha, til en viss grad, og som alle elever kan utvikle (0.6) ikke nødvendigvis en medfødt, statisk ferdighet (0.2) som skoler dre:per (.) o:g dette perspektivet kan også ses i relasjon til carol Dweck sitt syn på intelligens som (0.7) Hopfenbeck refererer da (0.8)til For Dweck hevder at intelligens utvikles over tid, og at vi, $i$ møte med utfordringer, stadig vil kunne lære mer (0.2) som igjen knyttes opp mot selvregulert læring og effekten det kan ha for utvikling av elevers intelligens (.) jeg kommer litt tilbake til selvregulert læring (.) eh men på pensum har vi også sawyer (.) og hans perspektiv på e:h kreativitet (0.2) og slik jeg forstår det, så knytter han det (.) mer opp mot kunstfagene, og det interaktive og sosiale aspektet ved læring, >samhandlingsaspektet< (.) og han beskriver det kreative produktet som noe (.) nytt (.) han også, og noe som vokser frem over tid (0.3) og som et produkt av idéer bidratt av mange forskjellige individer, samlet sammen, gjennom samarbeid og samtale (.) han bruker begrepet "collaborative emergence", tett tilknyttet til kreativitet (1.3) JA Så dette var altså noen tanker relatert til pensum og kreativitet (1.3) men jeg tenkte også å se litt på policy-dokumenter (.) fordi jeg tok en rask opptelling, skal vi se (1.5) eh I NOU 2015, fremtidens skole, så telte jeg opp at kreativitet blir nevnt hele 37 ganger (.) og bare det tyder jo på at det har relevans for fremtidens skole (0.2) og $i$ stortingsmelding 28 så blir kreativitet nevnt seks ganger, og da spesielt relatert til kognitive ferdigheter (1.7) mens $i$ overordnet del av læreplanen, så blir begrepet kreativitet, eller kreative faktisk, nevnt fem ganger (1.7) og da kobles det opp mot at elevene blant annet skal utvikle kreative evner, kreative ferdigheter eller kreativ tenkning så basert på den raske opptellingen, så kan det tyde på at begrepets relevans har blitt nedgradert (1.8) MEN det er her jeg synes det blir interessant fordi (.)

I linje 1-10 ser vi hvordan Louise forteller om sin lesing av Vygotskys tekst om kreativitet - «Imagination and creativity in childhood» - og reflekterer over hvordan dette skiller seg fra en mer statisk forståelse av kreativitet (L 12-14). I linje 15-28 utdyper hun hvordan hun oppfatter Vygotskys posisjon i forhold til tekster av Therese Hopfenbeck og Keith Sawyer, før hun i linje 30 går over til å gjenkjenne begrepet i policy-dokumentene NOU «Fremtidens skole» og 
Stortingsmelding 28 (2015-2016) - og senere overordnet del av læreplanen Kunnskapsløftet (L 36). ${ }^{1}$

I dette utdraget demonstrerer Louise at hun har lest og reflektert over store deler av litteraturen som omhandler kreativitet og læring. Selv om ikke alle studentene har gjort en så systematisk gjennomgang, kunne foreleseren trekke på Louises arbeid i gruppen. Blant annet dannet Louises videolekse grunnlag for å demonstrere en lesestrategi som kunne tas videre med til de andre studentene: Fremfor å lese hver tekst fra begynnelse til slutt, synes det fruktbart å søke sammenheng mellom ulike fagbegreper og følge hvordan disse brukes på tvers av emnelitteraturen. En slik lesestrategi ble fremhevet som én av flere alternativer når eksamen nærmet seg. For at en slik oppgave skal være meningsfull, forutsettes det imidlertid at emnelitteraturen bygger på en underliggende logikk som studentene kan utforske. Studentenes læring gjennom selvstendig lesing står i så måte i et avhengighetsforhold til emneinnholdet.

Louises argumentasjon kan også ses som demonstrasjon av et kunnskapssyn, der hun er orientert mot ulike teorier og forståelsessystemer - med et fokus på hvordan disse får betydning i skolens styringsdokumenter så vel som egen praksis. Litteraturlisten i emnet omfatter både internasjonal og nasjonal forskning, forskningsoppsummeringer og empiriske studier om de samme temaene og med de samme begrepene. At disse tekstene utgjør ulike kunnskapskilder som belyser de samme fenomenene på ulike måter kan være frustrerende. Særlig om man har en forståelse av forskningsbasert kunnskap som «sann», og at dersom ulike forskningsarbeider viser ulike ting så er én av dem feil. Louise kan i så måte ses som et eksempel på en som håndterer de ulike kildene på en fleksibel måte. I avslutningen av utdraget (L 42) ser vi også at det er først når vi forlater utdraget, at hun vektlegger MEN og går over i en mer vurderende fase. Det er først her hun signaliserer at grunnen er lagt for å selv trekke noen slutninger. Disse kommer først som respons på forskningsgjennomgangen. Selv om dette er en sjeldent systematisk videolekse, er dette bare ett av flere eksempler på at studenter aktivt søker seg mot å vise ulike perspektiver og også leter aktivt etter konsistens og konflikt mellom ulike tekster og posisjoner.

\footnotetext{
${ }^{1}$ Dette er kildene Louise referer til:

Hopfenbeck, T. N. (2014). Strategier for laering : om selvregulering, vurdering og god undervisning. Oslo: Universitetsforlaget.

Kunnskapsdepartementet (2006). Læreplanverket for Kunnskapsløftet (Midlertidig utg. juni 2006). Oslo: Kunnskapsdepartementet.

NOU 2015: 8 (2015). Fremtidens skole - Fornyelse av fag og kompetanser. Hentet fra www.regjeringen.no Sawyer, R. K. (udatert). How to transform schools to foster creativity. Hentet fra http://keithsawyer.com/PDFs/TCR.pdf

Vygotsky, L. S. (2004). Imagination and Creativity in Childhood. Journal of Russian \& East European Psychology, 42(1), 7-97.
} 


\section{Profesjonsspesifikke begreper som linse for å betrakte og utvikle egen undervisning}

Dette siste utdraget gir en illustrasjon på måter studentene kan koble undervisningen på universitetet til undervisning i skolen. Christian arbeidet som lærer parallelt med utdanningen, og i dette utdraget ser vi Christian reflektere over sin lesing siden sist og hvordan han så relevans for undervisningen på sin skole. Dette utdraget er valgt fordi det viser et tilfelle der lesingen og emnebegrepene tas i bruk som ressurser for å analysere og utvikle egen praksis.

Utdrag 4: Christian, om profesjonsspesifikke begreper fra teori til undervisningspraksis:

1 Yes. ja skal jeg prøve å fortelle litt om det jeg har lest (.) 2 og litt om hvordan det har gått (0.8) jeg har ikke fått lest 3 ekstremt mye så ærlig må jeg bare være ((setning tatt ut for 4 anonymisering)) Så: : (1.0) Men jeg har lest Collins og Halverson, 5 The Second Educational Revolution og den var veldig, veldig 6 interessant (0.9) og jeg synes de:n tar opp veldig mange spennende 7 temaer og det fikk meg til å tenke over min egen praksis her på 8 skolen (0.8) de snakker om dette med digital revolusjon og hvordan 9 skolen har utfordringer med å tilpasse seg den nye æraen som 10 oppstår nå med digitale artefakter, som det blir sagt (1.0) og 11 hvordan den setter ting opp mot hverandre dette med universell 12 læring versus tilpasset læring den setter opp lærer som ekspert 13 (0.6) motsatt til å være en formidler I forhold til å lære dem å 14 bruke informasjonskilder $(0.6)$ standardisert vurdering mot 15 spesialisering, dette at du får mye større muligheter til å 16 tilpasse OG DEt (1.0) satte $i$ gang en refleksjon hos meg rundt 17 hvordan jeg jobber og min skole jobber og (0.9) ga meg egentlig 18 mange (.) tanker rundt hvordan jeg kan bruke disse digitale 19 artefaktene til $(0.7)$ å sette opp undervisningen og legge opp 20 undervisningen ... designe ((smil)) undervisningen på en annen måte 21 (0.7) Så jeg har gjort det FØr (.) brukt flipped classroom og jeg 22 har nå gjort det igjen ((setning tatt ut for anonymisering)) og 23 jeg har gitt den type lekser som vi har fått selv, her på studiet 24 (0.7) Og jeg har ikke rukket å se på det ennå, men det virker 25 veldig spennende, og elevene syntes det var veldig ålreit (1.1) 26 og det gjør at jeg ser at jeg kan bruke disse digitale mulighetene 27 $i$ mye større grad, inn $i$ min egen undervisning

I linje 1-3 ser vi hvordan Christian forteller at han ikke har fått lest så veldig mye, og på denne måten senker seerens forventninger til omfang. Dette kan også tolkes som at han tar høyde for at forståelsen for tekstene han har lest kan endre seg når han får mer oversikt.

Fra linje 8 synliggjøres et interessant tema som vi ser at videoleksene tilrettelegger for; at studentene tar i bruk og anvender fagspesifikke begreper i argumentasjon. Som vi ser ut fra understreking av trykk og markering av pauser, markeres disse fagbegrepene på en måte som skiller seg fra den naturlige flyten av ord. Dette kan tyde på at fagbegrepene ennå ikke er inkorporert som en naturlig 
del av studentens vokabular, eller at han anerkjenner videoleksa som en slags øvings- eller testsituasjon og fremhever begrepene som en form for avtale med underviserne. Han fremhever ideene som interessante for hans praksis (L 18), men måten han markerer «designe undervisningen» som en endring av «legge opp undervisningen» viser også oppmerksomheten mot funksjonen til videoleksene som en arena for å prøve ut emnerelaterte nyord.

Fra linje 21 ser vi et annet interessant aspekt ved denne refleksjonen, at han orienterer seg mot den konkrete undervisningen han har hatt som lærer, og hvordan han selv har tatt i bruk videolekser som ressurs i undervisningen. Samlet illustrerer dette hvordan videoleksene, som andre læringsaktiviteter i lærerutdanning, kan skape både refleksjon og faglig forståelse - men også inspirere studentenes fremtidige undervisningspraksis i skolen.

\section{Analyse III:}

\section{Evaluering og videreutvikling av videolekseprosjektet}

Etter første års gjennomføring dannet Analyse II og tilbakemeldinger fra studentene utgangspunkt for neste gjennomføring. Følgende to forbedringer ble bestemt for den påfølgende års arbeid med videolekser:

For det første ble studentene vist eksempler fra tidligere studenters videolekser og gjort oppmerksomme på at det var fruktbart å orientere lesingen rundt sentrale begreper og prinsipper i faget, fremfor å lese emnelisten «fra A til Å». Kjernebegrepene ble også forsøkt synliggjort på samlingene. For eksempel laget klassen et felles tankekart som tok utgangspunkt i kjernebegrepene.

For det andre ble det gitt individuelle tilbakemeldinger til studentene på videoleksene deres med innspill til lesingen. Etter gjennomføring av første år ble det tydelig at underviserne opplevde at videoleksene hadde potensial for å bli kjent med studentene, følge deres læreprosess og en ressurs for samarbeid mellom underviserne - men i studentevalueringen kom det frem at hvordan dette påvirket undervisningen ikke var like åpenbart for studentene. I gjennomføringen av andre år ble det derfor skrevet tilbakemeldinger i systemets chat-funksjon fortløpende mens studentvideoene ble spilt av. På denne måten fikk studentene tilbakemeldinger, uten at underviserne brukte særlig mer tid enn bare ved å se videoene. Typisk inneholdt tilbakemeldingene en anerkjennelse og noen tips til videre lesing. Studentenes forslag og ønsker for forelesningen som kom, ble også notert fortløpende for undervisernes videre planlegging.

I etterkant av gjennomføringen av emnet andre år ble det gjennomført en studentevaluering som orienterte seg særlig mot videoleksene. Her ble det blant annet spurt: Hvor enig er du i følgende påstander? 


\begin{tabular}{|c|c|c|c|c|c|}
\hline & $\begin{array}{l}\text { Svært } \\
\text { uenig }\end{array}$ & Uenig & $\begin{array}{l}\text { Verken enig } \\
\text { eller uenig }\end{array}$ & Enig & $\begin{array}{l}\text { Svært } \\
\text { enig }\end{array}$ \\
\hline Videolekser gjør at jeg leser jevnere gjennom semesteret & 0 & 0 & 5 & 8 & 6 \\
\hline Videolekser er nyttige fordi forelesningene treffer bedre på ting jeg er opptatt av & 0 & 1 & 5 & 11 & 2 \\
\hline Videolekser er nyttige fordi jeg får en anledning til å snakke i/om fag og begreper & 0 & 1 & 2 & 10 & 8 \\
\hline Jeg vil gjerne ha en individuell kommentar fra foreleser på videoleksen min & 0 & 0 & 0 & 2 & 17 \\
\hline Jeg kan tenke meg å bruke video på lignende måter i min egen underv & 0 & 0 & 0 & 7 & 13 \\
\hline
\end{tabular}

Figur 1. Utdrag fra studentevaluering

I figur 1 er det interessant at studentene skårer videoleksene så høyt på flere såpass ulike parametere. Dette gir en indikasjon på at studentene har opplevd videoleksene som nyttige på flere måter. Men slike selvevalueringer bør også vurderes kritisk. Eksempelvis er det på det andre spørsmålet vanskelig for studentene å vurdere hvordan forelesningene ville vært uten videoleksene. Det nest siste spørsmålet gir derimot en klar pekepinn på at endringen på andre år med en individuell kommentar oppleves viktig.

Etter at begge år var gjennomført, ble alle studentenes videolekser behandlet i analyseverktøyet NVivo med koder som ble generert fra materialet. Dette gir en oversikt som bygger på og supplerer interaksjonsanalysene i forrige delkapittel, ved å synliggjøre overordnede mønstre i hvordan studentene tok i bruk videoleksene gjennom begge år. Et første sett med koder ble etablert som ekskluderende kategorier som gir oversikt over hvilke orienteringer studentene hadde når de snakket i videoen:

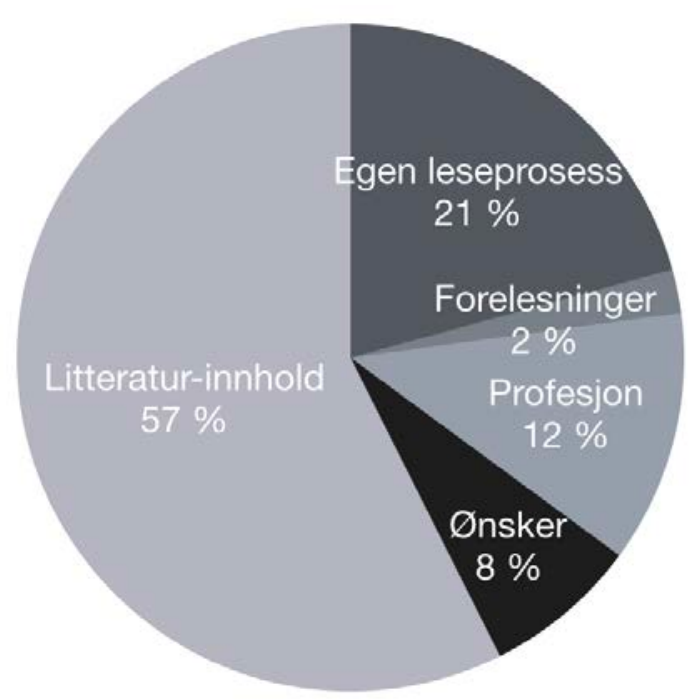

Figur 2. En oversikt over hvordan studentene tok videoleksene i bruk. Data fra begge år er samlet i diagrammet. Kodene er brukt ekskluderende og diagrammet dekker det totale antallet transkriberte ord i videoleksene. Prosent representerer andel kodede ord av totalen.

\section{Koder:}

Egen leseprosess:

Overordnet refleksjon over egen lese- og læreprosess

Forelesninger:

Reflekterer over temaene i relasjon til undervisning og foredrag de har vært på, i emnet eller $\mathrm{i}$ andre sammenhenger

Profesjon:

Reflekterer over temaene i relasjon til praksissituasjoner, utdanningspolitikk eller fremtidig yrke

Ønsker:

Studentene kommer med ønsker for hva som skal tas opp på neste samling

Litteraturinnhold:

Reflekterer over, forteller om eller drøfter innholdet i emnelitteraturen 
I figur 2 blir det tydelig at studentene i stor grad benytter videoleksene til å reflektere over egen lese- og læreprosess. Dette er i hovedsak refleksjoner som: «Jeg har da startet med å lese denne boka her, som heter Lereren som regissør. Her har jeg rukket å lese fra kapittel 1 til 6. Jeg synes kapitlene var veldig fine, det var veldig mye repetisjon, men det var nyttig.» Her inkluderte vi også enkelte refleksjoner over selve videoleksene, som vist i utdrag 1 . Et stort flertall av studentene reflekterte i større eller mindre grad over egen leseprosess, og koden er representert i 77 av 98 videolekser.

Koden «Forelesninger» markerer deler av videoleksene hvor studentene diskuterer litteratur i relasjon til undervisning og foredrag de har vært på - i dette emnet eller andre sammenhenger.

Koden «Profesjon» omfatter de delene av videoleksene der studentene reflekterer over emnelitteraturen i lys av ulike erfaringer fra praksis, utdanningspolitikk eller fremtidige jobbsituasjoner. Den fruktbare koblingen mellom forskning og profesjonsutøvelsen som Christian (utdrag 4) fremviste, er del av det som inkluderes her. I lys av at slike koblinger fremsto som en fruktbar orientering $\mathrm{i}$ analysen, er andelen ikke spesielt høy. Dette bør imidlertid ses i relasjon til at det i år to ble gitt en spesifikk videolekse der studentene skulle reflektere nettopp over erfaringene i praksisperioden sin mot temaer i emnelitteraturen. Som forklart under «Data» i kapittel 4, ble denne leksa imidlertid ikke kodet, siden oppgaven skilte seg fra de rene leserefleksjonene.

Koden «Ønsker» omfattet typisk spørsmål om ulike begreper og tekster som kunne tas opp på forelesning, samt ønsker for gjennomføringen av samlingene for eksempel at de gjerne ville ha flere helklassediskusjoner. I denne kategorien var det stor forskjell på hvor lang tid som ble brukt til spørsmålene, og mange stilte ikke spørsmål i det hele tatt selv om det var en del av oppgaven. Koden er representert i 46 av 98 filmer. Noen ganger sa studentene at de ikke hadde spørsmål fordi de var fornøyd, andre ganger fikk de for knapt med tid innenfor de 5 minuttene de hadde til rådighet.

Den største andelen av videoleksene besto av at studentene reflekterte over, fortalte om eller drøftet innholdet i emnelitteraturen. Selv om kodene er brukt ekskluderende, var det ikke alltid et helt klart skille mellom «Egen leseprosess» og «Litteraturinnhold». Disse ble likevel skilt relativt godt gjennom å vurdere om argumentasjonen orienterte seg mot tekstene og organiseringen av lesingen eller om studenten forklarte innholdet i tekstene.

Som vist i analysen av samtaleutdrag i forrige delkapittel, så hadde refleksjonene over «Litteraturinnhold» til dels ulik karakter. I etterkant av den overordnete kodingen med ekskluderende kategorier vist i figur 2, ble det derfor laget en mer analytisk kategori inspirert av den formen for lesing som Louise demonstrerte i utdrag 3. Koden «Drøfter på tvers» ble brukt som en underkategori av koden «Litteraturinnhold» og definert som at det samme fagbegrepet/temaet ble drøftet på tvers av to eller flere kilder. 


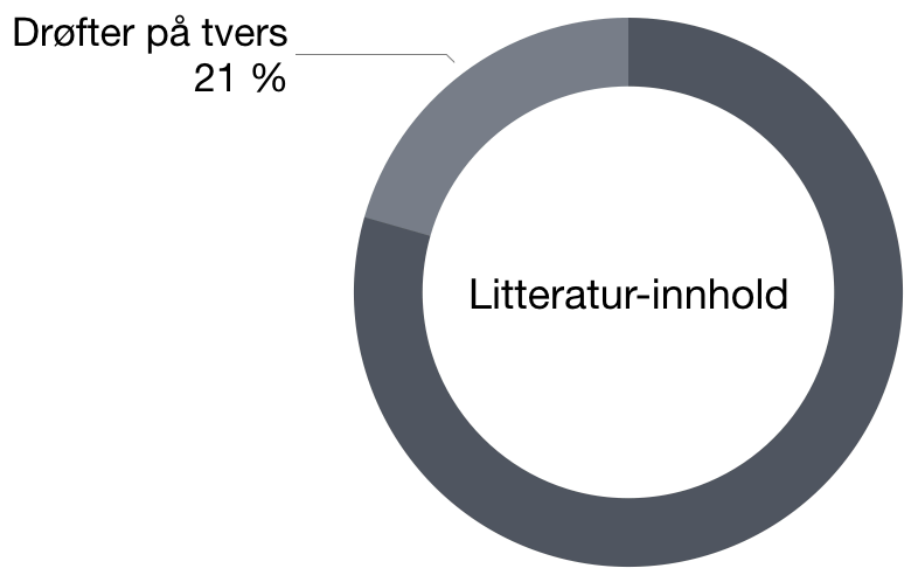

Figur 3. Andel av koden «Litteraturinnhold» i figur 2 som inneholder det vi har kodet som «Drøfter på tvers»

I figur 3 blir det tydelig at $21 \%$ av «Litteraturinnhold» er kategorisert som «Drøfter på tvers». Når vi ser på hvor mange av studentene som drøfter litteraturen på denne måten, er det kun 17 av 47 studenter som har videolekser med denne koden. I lys av dette vurderer vi at $21 \%$ er relativt høyt, og tyder på at de studentene som drøfter på denne måten har innholdsrike videolekser og drøfter på denne måten i en stor andel av videoen sin.

Som beskrevet over representerer «Drøfter på tvers» en lesestrategi som studentene ble oppfordret til å benytte seg av, og det ble gitt eksempler, laget målrettede gruppeaktiviteter og fremhevet i tilbakemeldinger. Det er imidlertid interessant at når videoleksene fra første år og andre år sammenlignes, så er det ikke utpreget forskjell på andelen av «Drøfter på tvers». Dette kan forklares med at det er relativt små grupper der studentene har ulik grad av eksisterende strategier og ulike forutsetninger og engasjement, men det kan også forklares ved at det er behov for enda tettere oppfølging, forventninger og støtte for å skape tydelig endring i måten å lese, reflektere og drøfte forskningslitteratur på.

\section{Diskusjon}

Denne artikkelen har analysert utviklingen av videolekser som et resultat av, og ressurs for, samarbeid mellom en lærer i kombinasjonsstilling og underviserne på universitetet. Det første forskningsspørsmålet var:

- Hvordan tok studentene videoleksene i bruk for å reflektere over egen leseprosess, diskutere emnelitteratur og prøve ut profesjonsspesifikke begreper?

Analysen av studentenes refleksjonsvideoer viser flere trekk som er interessante fra lærerutdanneres perspektiv, og som har relevans for forskning og videre utvikling: 
For det første er det viktig å legge merke til videoleksenes potensial som gjensidig ansvarliggjørende for studenter og undervisere. Videoleksene skaper struktur for leseprosessen, og gjør det også mulig for underviserne å forberede seg og møte studentenes ønsker og behov. Utdrag 1 og 4 synliggjorde eksempler på hvordan studentene ansvarliggjøres for lesingen, og at det har en viss kostnad ikke å ha forberedt seg. Men man bør også vurdere kritisk i hvor stor grad lesingen av faglitteratur bør styres og monitoreres, uten å komme i konflikt med et akademisk ideal om utvikling av en selvstendig posisjon som fagperson. At studentene er vare for slike signaler, er blant annet synlig i utdrag 2, der Iben stiller spørsmål ved hvordan teorien egentlig bør og kan brukes. Videoleksene kan fort oppfattes som en detaljstyring av hvilke refleksjoner som er «riktige», noe som er uheldig. Derfor valgte vi eksempelvis ikke å gi lesebestillinger på bestemte tekster til hver gang, men heller vektlegge at de leste og anvendte de ulike tekstene som ressurser for å se problemstillinger på ulike måter.

For det andre demonstrerer utdragene - spesielt Christian i utdrag 4 - hvordan videoleksene skaper en arena for å ta i bruk og artikulere faglige begreper og ideer. Slik Brown et al. (1989) fremhever, er slik tilegnelse av begreper som verktøy for å argumentere og reflektere, i kjernen av læring. Goodwin $(1994,1995)$ har også vist hvordan faglige begreper danner ressurser for å se og konseptualisere verden på profesjonsspesifikke måter. Dette er prosesser som også vil utspille seg på forelesninger og i praksissituasjoner, men videoleksene kan danne en øvingsarena med mulighet for mer direkte tilbakemeldinger. Både Iben i utdrag 2 og Christian i utdrag 4 viser hvordan teori kan bidra til undervisningspraksis; det å skape slike koblinger er adressert som en av de store utfordringene i lærerutdanning i både forskning og policy (Ellis, 2016; Meld. St. 16 (2016-17)).

For det tredje er det tydelig hvordan videoleksene gjør den «tause» leseprosessen (Baker et al., 2019) tilgjengelig for vurdering og tilbakemelding. I utdrag 3 viser Louise hvordan hun har lest og vurdert det samme begrepet gjennom flere ulike forskningsstudier, og også opp mot skolens styringsdokumenter. Noen studenter brukte videoleksene til å gi mer resyme-lignende presentasjoner av tekstenes innhold, mens Louises strategi om å følge et begrep på tvers av litteraturen i større grad innebærer en form for analyse av innholdet. En slik orientering mot kunnskap som prosess og under utvikling kan synes som en konstruktiv tilnærming til høyere utdanning (Buehl \& Fives, 2009, s. 372). Resultatet av kodingen viser også at dette er aspekter som kan styrkes i en videreføring av prosjektet. Det kan for eksempel være et konstruktivt mål for en videreføring å øke andelen av «Drøfter på tvers». Funnene i denne studien tyder imidlertid på at det ikke er tilstrekkelig å gjøre studentene oppmerksomme på dette, men at det heller bør utformes mer konkrete lesebestillinger eller tettere oppfølging. Dette støtter tidligere studier som viser at tydelig innramming av leseaktiviteten har stor innflytelse på studentenes læreprosess (Marton \& Säljö, 1976). 
Det andre forskningsspørsmålet var:

- Hvordan ble videolekser etablert som et felles objekt for samarbeid mellom undervisere i høyere utdanning?

I dette emnet ble videoleksene del av den felles forberedelsen som underviserne på universitetet og læreren i kombinasjonsstilling gjorde før hver samling. Introduksjonen av videolekser er i så måte et resultat av at arbeidsmåter fra skolen omarbeides inn i lærerutdanningen. Læreren i kombinasjonsstilling hadde bred erfaring med nettbaserte arbeidsmåter, og gjennom samarbeidet med emneansvarlige ble deler av dette innarbeidet i en ny modell for å løse opplevde utfordringer i lærerutdanningen. Stillingskategorien fikk på denne måten en posisjon i å revitalisere undervisningsmåtene i emnet, og også en måte å bringe en stemme fra partnerskolen inn i forelesningene på campus. På den annen side ble læreren i kombinasjonsstilling involvert i forskningsaktivitet - som er en av universitetets kjernevirksomheter - blant annet gjennom arbeidet med denne studien.

Studien demonstrerer verdien av å ha konkrete samarbeidsprosjekter og hvordan videolekser kan anvendes for å gi undervisere med ulik fagbakgrunn felles orientering mot studenters lese- og læringsprosess. På denne måten synliggjøres muligheten for å skape et studentorientert utgangspunkt for samarbeid og partnerskap. Utdragene fra studentenes videolekser demonstrerer potensial for å skape en type konstruktiv friksjon og debatt om ulike perspektiver og kunnskapsformer. Ved innføringen av stillingstypen lærer i kombinasjonsstilling i dette emnet, var det et viktig premiss at denne ikke skulle brukes som en måte å «outsource» deler av undervisningen på, men at undervisningen skulle gjennomføres i fellesskap. Prosjektet har i så måte potensial som arena for refleksjon over de ulike kunnskapsformene som kjennetegner lærerprofesjonen (Hermansen \& Mausethagen, 2016).

\section{Avsluttende kommentarer}

Denne artikkelen har drøftet bruken av videolekser som grenseflate mot studentenes lese- og læreprosess. Selv om analysen er koblet mot de konkrete studentproduktene, har vi også lagt vekt på hvordan en rekke institusjonelle, teknologiske og relasjonelle vilkår har spilt inn. I tråd med det teoretiske rammeverket er det vist hvordan læringsaktiviteten ikke kan ses som programmert i den digitale infrastrukturen - men at den sosiale og institusjonelle innrammingen og bruken er avgjørende for at studentenes videorefleksjoner får en funksjon inn i studentenes læring og utviklingen av samlingene.

Partnerskapet mellom læreren i kombinasjonsstilling og de øvrige underviserne på universitetet kan vurderes på samme måte. Selv om opprettelsen av 
stillingen og ressursene gir noen generiske muligheter, så er det i det konkrete samarbeidet at målsettingene om økt relevans og sammenheng mellom de ulike kontekstene for læring realiseres. I denne sammenheng dannet videoleksene et objekt for samarbeid der flere kunnskapsformer kunne aktualiseres og spille inn.

\section{Takk}

Forfatterne retter en stor takk til studentene som har deltatt i studien, både for deltakelsen og for innspill til utformingen av prosjektet. Takk til Læring og Undervisning i Digitale Omgivelser (LUDO) for støtte, samt til Hege Hermansen for gode innspill underveis. Vi vil også takke fagfellene for deres grundige og konstruktive kommentarer.

\section{Om forfatterne}

Magnus Hontvedt er førsteamanuensis ved Universitetet i Sørøst-Norge. Hans forskningsinteresser omfatter blant annet samarbeidslæring, vurdering og digitale læringsomgivelser i høyere utdanning.

Institusjonstilknytning: Institutt for pedagogikk, Universitetet i Sørøst-Norge, Postboks 235, 3603 Kongsberg.

E-post: magnus.hontvedt@usn.no

Morten Oddvik er lærer i kombinasjonsstilling ved Universitetet i Sørøst-Norge. Hans forskningsinteresser omfatter blant annet digital kompetanse, samhandlingspraksiser og vurdering i digitale læringsomgivelser. Han er også interessert i samarbeidslæring i teknologirike læringsomgivelser og digital kompetanseheving i profesjonsutdanningen.

Institusjonstilknytning: Fakultet for humaniora, idretts- og utdanningsvitenskap, Universitetet i Sørøst-Norge, Postboks 235, 3603 Kongsberg.

E-post: morten.oddvik@usn.no

Rakel Rohde Næss er førstelektor ved Universitetet i Sørøst-Norge. Hennes forskningsinteresser omfatter blant annet undervisning og læring innenfor lærerprofesjonen, hvordan skape gode feedback-kulturer, bruk av digitale mapper, veiledning og hvordan lærere arbeider med bruk av konstruerte læringsomgivelser for å øke studenters læringsutbytte og muligheter for samarbeidslæring. Institusjonstilknytning: Institutt for pedagogikk, Universitetet i Sørøst-Norge, Postboks 235, 3603 Kongsberg.

E-post: rakel.k.r.nass@usn.no 


\section{Referanser}

Allen, D. W. (1980). Microteaching: A personal review. British Journal of Teacher Education, 6(2), 147-151.

Asikainen, H. \& Gijbels, D. (2017). Do Students Develop towards More Deep Approaches to Learning during Studies? A Systematic Review on the Development of Students' Deep and Surface Approaches to Learning in Higher Education. Educational Psychology Review, 29(2), 205-234.

Baker, S., Bangeni, B., Burke, R. \& Hunma, A. (2019). The invisibility of academic reading as social practice and its implications for equity in higher education: a scoping study. Higher Education Research \& Development, 38(1), 142-156.

Bronkhorst, A. \& Akkerman, S. (2016). At the boundary of school: Continuity and discontinuity in learning across contexts. Educational Research Review, 19, 18-35.

Brown, A. (1992). Design Experiments: Theoretical and Methodological Challenges in Creating Complex Interventions in Classroom Settings. Journal of the Learning Sciences, 2(2), 141-178.

Brown, J., Collins, A. \& Duguid, P. (1989). Situated Cognition and the Culture of Learning. Educational Researcher, 18(1), 32-42.

Buehl, M. M. \& Fives, H. (2009). Exploring teachers' beliefs about teaching knowledge: Where does it come from? Does it change? Journal of Experimental Education, 77(4), 367-407.

Collins, A. \& Halverson, R. (2010). The second educational revolution: Rethinking education in the age of technology. Journal of Computer Assisted Learning, 26(1), 18-27.

Daniels, H. (2008). Vygotsky and research. London, England: Routledge.

de Lange, T. \& Nerland, M. (2018). Learning to Teach and Teaching to Learn: Exploring Microteaching as a Site for Knowledge Integration in Teacher Education. I P. Maassen, M. Nerland \& L. Yates (red.), Reconfiguring Knowledge in Higher Education (s. 169-185). Springer Nature.

Derry, S. J., Pea, R. D., Barron, B., Engle, R. A., Erickson, F., Goldman, R., ... Sherin, M. G. (2010). Conducting video research in the learning sciences: Guidance on selection, analysis, technology, and ethics. The Journal of the Learning Sciences, 19(1), 3-53.

Edwards, A. (2010). Being an Expert Professional Practitioner: The Relational Turn in Expertise. Dordrecht: Springer.

Edwards, A. \& D'Arcy, C. (2004). Relational agency and disposition in sociocultural accounts of learning to teach. Educational Review, 56(2), 147-155.

Edwards, A., Lunt, I. \& Stamou, E. (2010). Inter-Professional Work and Expertise: New Roles at the Boundaries of Schools. British Educational Research Journal, 36(1), 27-45.

Ellis, V. (2016). The challenge of transformation: $\AA$ arbeide med kunnskapsproblemet i lærerutdanningen. Acta Didactica Norge, 10(2), 366-374.

Finne, R., Jensberg, H., Aaslid, B., Haugsbakken, H., Mathisen, I. H. \& Mordal, S. (2011): Oppfatninger av studiekvalitet i lererutdanningen blant studenter, lcererutdannere, øvingslæerere og rektorer. Trondheim: SINTEF-rapport.

Fosse, B. O. (2016). Transformering av kunnskap mellom campus og skole i lærerutdanningen. Acta Didactica Norge, 10(2), 235-251. 
Gast, I., Schildkamp, K. \& Van der Veen, J. T. (2017). Team-based professional development interventions in higher education: A systematic review. Review of Educational Research, 87(4), 736-767.

Goodwin, C. (1994). Professional vision. American Anthropologist, 96(3), 606-633.

Goodwin, C. (1995). Seeing in depth. Social Studies of Science, 25(2), 237-274.

Heller, V. \& Morek, M. (2015). Academic discourse as situated practice: An introduction. Linguistics and Education, 31, 174-186.

Hermansen, H. \& Mausethagen, S. (2016). Når kunnskap blir styrende: Læreres rekontekstualisering av nye kunnskapsformer. Acta Didactica Norge ,10(2), 92-107.

Hovdenak, S. S. \& Wiese, E. (2017). Fronesis: veien til profesjonell lærerutdanning? Uniped, 40(02), 170-184.

Jahreie, C. F. (2010). Learning to teach. An activity-theoretical study of student teachers' participation trajectories across boundaries. Doktoravhandling, Det utdanningsvitenskapelige fakultet, Universitetet i Oslo.

Jordan, B. \& Henderson, A. (1995). Interaction analysis: foundations and practice. The Journal of the Learning Sciences, 4(1), 39-103.

Kay, R. (2012). Exploring the use of video podcasts in education: A comprehensive review of the literature. Computers in Human Behavior, 28(3), 820-831.

Kourieos, S. (2016). Video-Mediated Microteaching - A Stimulus for Reflection and Teacher Growth. Australian Journal of Teacher Education, 41(1), 65-80.

Krange, I. \& Ludvigsen, S. (2009). The historical and situated nature design experiments Implications for data analysis. Journal of Computer Assisted Learning, 25(3), 268-279.

Kunnskapsdepartementet (2017). Lærerutdanning 2025. Nasjonal strategi for kvalitet og samarbeid i lærerutdanningene. Oslo: Kunnskapsdepartementet.

Lundin, M., Bergviken Rensfeldt, A., Hillman, T., Lantz-Andersson, A. \& Peterson, L. (2018). Higher education dominance and siloed knowledge: a systematic review of flipped classroom research. International Journal of Educational Technology in Higher Education, 15, Art. 20. https://doi.org/10.1186/s41239-018-0101-6

Mahoney, P., Macfarlane, S. \& Ajjawi, R. (2019). A Qualitative Synthesis of Video Feedback in Higher Education. Teaching in Higher Education, 24(2), 157-179.

Marton, F. \& Säljö, R. (1976). On qualitative differences in learning II: Outcome as a function of the learner's conception of the task. British Journal of Educational Psychology, 46, 115-127.

Meld. St. 16 (2016-2017). Kultur for kvalitet i høyere utdanning. Oslo: Kunnskapsdepartementet.

Meyer, E. \& Forester, L. (2015). Implementing Student-Produced Video Projects in Language Courses: Guidelines and Lessons Learned. Unterrichtspraxis/Teaching German, 48(2), $192-210$.

NOKUT (2006). Evaluering av allmennlererutdanningen i Norge 2006. Del 1: Hovedrapport. Hentet 01.05.2019 fra

https://www.nokut.no/contentassets/40568ec86aab411ba43c5a880ae339b5/alueva_hovedra pport.pdf 
Nolen, S. B., Horn, I. S., Ward, C. J. \& Childers, S. A. (2011). Novice Teacher Learning and Motivation across Contexts: Assessment Tools as Boundary Objects. Cognition and Instruction, 29(1), 88-122.

Petraglia, J. (1998). The real world on a short leash: the (mis)application of constructivism to the design of educational technology. Educational Technology Research and Development, 46(3), 53-65.

Roth, W.-M. (2006). Doing Qualitative Research: Praxis of Method. Rotterdam: Sense Publishers.

Sannino, A., Daniels, H. \& Gutiérrez, K. (2009). Activity Theory Between Historical Engagement and Future-Making Practice. I A. Sannino, H. Daniels \& K. Gutiérrez (red.), Learning and Expanding with Activity Theory (s. 1-16). Cambridge University Press.

Silseth, K. (2012). The multivoicedness of game play: Exploring the unfolding of a student's learning trajectory in a gaming context at school. International Journal of ComputerSupported Collaborative Learning, 7(1), 63-84.

Suppes, F. (1974). The Place of Theory in Educational Research. Educational Researcher, 3, 3-10.

Säljö, R., Gilje, Ø. \& Goveia, I. C. (2016). Lœring: En introduksjon til perspektiver og metaforer. Oslo: Cappelen Damm akademisk.

USN (2019a). Utviklingsavtalen. USN Profesjon, Universitetet i Sørøst-Norge. Hentet 18.05.2019 fra: https://www.usn.no/om-usn/utviklingsavtalen/usn-profesjon/

USN (2019b) Beskrivelse og retningslinjer for Hospiteringsordninger og Kombinasjonsstillinger mellom Universitetet i Sørøst-Norge og barnehagefeltet og grunnopplcringen. Universitetet i Sørøst-Norge. Hentet 18.05.2019 fra: https://www.usn.no/omusn/utviklingsavtalen/usn-profesjon/kombinasjonsstillinger/

Vygotsky, L. S. (1978). Mind in society: The development of higher mental processes. M. Cole, S. Scribner, V. John-Steiner \& E. Souberman (red.). Cambridge, MA: Harvard University Press. 